\title{
DAMPAK SOSIAL BUDAYA PARIWISATA : STUDI KASUS DESA WISATA PULESARI DAN \\ DESA EKOWISATA PANCOH
}

\author{
Elisa Dwi Rohani \\ Bisnis Perjalana Wisata Sekolah Vokasi, Universitas Gadjah Mada \\ Email: elisa.dwi.rohani@ugm.ac.id \\ Nuryuda Irdana \\ Bisnis Perjalana Wisata Sekolah Vokasi, Universitas Gadjah Mada \\ Email: nuryuda.irdana@ugm.ac.id
}

\begin{abstract}
Tourism can be seen not only as an economic phenomenon, but also as a socio-cultural phenomenon. Tourism is a phenomenon of cultural interaction which ultimately affects the cultural changes and behavior of local people as tourism actors. This study aims to provide a different picture related to the impact of tourism by presenting an overview of the socio-cultural life of the community after tourism activities in tourist villages. In this study using a comparative study method. The positive impacts that occur between the two villages are very different in social aspects, namely: 1) The spirit of the community that naturally awakens in the Pulesari tourist village, 2) strengthening organization (strengthening the organization), 3) the emergence of leaders (the emergence of leaders). While the negative impacts from the social aspect include 1) the impact that occurs in the community (Community Division) 2) social problems (social problems) related to drugs or prostitution, 3) Conflicts begin to emerge in the form of the emergence of new tourist villages that carry the same concept. Cultural events that occur include 1) preservation of local culture (preservation of local culture), 2) exchange of information between hosts and guests regarding village potential, arts, traditions, customs, patterns, patterns of life and culture that lead to deeper interactions. While the negative impacts that occur include 1) commercialization of culture, 2) imitating other cultures (imitating other cultures).
\end{abstract}

Keywords: Impact, Socio-cultural, Tourism, Tourism Village 


\section{Pendahuluan}

Pembicaraan mengenai dampak social budaya pariwisata sudah mendapatkan perhatian dari banyak pihak. Sejak dekade 1970-an sampai dengan dekade 1990-an paling tidak tercatat ada 17 ahli yang menyoroti fenomena sosial budaya yang ditimbulkan pariwisata (Pitana \& Gayatri, 2005), masing-masing dengan tesis mengenai hubungan-hubungan dan dinamika tuang rumah dan tamu (host-guest). Namun seperti yang disebutkan (Pitana \& Gayatri, 2005) terdapat benang merah dari kajian-kajian dampak sosial budaya pariwisata dimanapun, yaitu terjadinya dinamika dan bahkan terjadinya perubahan dalam struktur internal suatu masyarakat. Pariwisata menjadi pembeda antara masyarakat yang bersentuhan dengan industri pariwisata dan mereka yang tidak.

Mengukur besaran dampak sosial budaya pariwisata terhadap masyarakat tidaklah mudah salah satu kendala utama adalah dalam pemerolahan data, hal ini dikarenakan data yang dipergunakan untuk mengukur dimensi sosial budaya ini bisa sangat bersifat subjektif. Dampak bisa mudah ditemukenali dengan merujuk pada data-data sekunder yang sudah ada, seperti tingkat kriminalitas, penyalah gunaan narkoba, dan prostitusi, namun indikator-indikator ini juga tidak sepenuhnya dikaitkan pariwisata karena bisa saja merupakan dampak dari hal lain, intrusi media yang massif (Cooper dkk, 1998). Namun demikian, kajian dimensi sosial budaya pariwisata di desa wisata Pulesari dan desa wisata Pancoh akan membahas tentang dampak positif maupun dampak negatif yang timbul dari kegiatan pariwisata.

Berangkat dari permasalahan yang ada, maka dalam kajian ini berusaha untuk mencapai sasaran yaitu mengambarkan pengaruh pariwisata terhadap sosial budaya masyarakat setempat setelah ditetapkan sebagai desa wisata. Kajian ini bertujuan untuk memberikan gambaran yang berbeda terkait dampak pariwisata, pada umumya dampak dikaitkan dengan sektor ekonomi tetapi dalam kajian ini meyajikan gambaan bagaimana kehidupan social budaya masyarakat pasca adaya aktivitas 
pariwisata didesanya,dampak social dan budaya apa yang terjadi dalam struktur masyarakat di desa wisata Pulesari dan desa wisata Pancoh, megupas lebih dalam bagaimana bentuk dinamika sosial (social dynamics), Interaksi dalam masyarakat, pola prilaku masyarakat maupun perubahan masyakat dan kebudayaan.

Bukan tanpa alasan jika dalam penelitian ini menggunakan kata dampak yang dirasa cukup mampu mewakili keresahan yang terjadi akibat perkembangan pariwisata, karena definisi dampak yang mampu mewakil efek berganda dari kegiatan pariwisata disuatu kawasan. Dalam kajian-kajian pariwisata, telah banyak hasil kajian maupun penelitian yang membahas tentang dampak ekonomi pariwisata, tetapi masih sangat sedikit yang membahas dampak sosial budaya terhadap pariwisata. Dampak ekonomi pariwisata dianggap lebih penting dan lebih menarik untuk dibahas dari pada dampak sosial budaya pariwisata, meskipun secara langsung dan tidak disadari dampak sosial dan budaya juga terjadi. Oleh sebab itu dalam penelitian ini akan lebih banyak membahas berbagai macam dampak social dan budaya yang ditimbulkan dari kegiatan pariwisata, baik itu dampak positif maupun dampak negatif dan pengaruhnya terhadap kehidupan masyarakat.

Desa wisata diinisiasi mulai tahun 2001 didesa Tanjung salah satu desa di Provinsi DIY. Perjalanan perkembangan desa wisata cukup panjang, banyak perubahan dan penataan yang terjadi, namun seiring berjalannya waktu desa wisata banyak berbenah sehingga seperti saat ini. Dari dana segar sampai dana bergulir banyak diterima desa wisata yang merupakan perpaduan dari semua unsur didesa, dengan bisnis utama dibidang pertanian, peternakan, dan perikanan. Bisnis masyarakat ini banyak dilirik dan mempunyai prospek jangka panjang, dan merupakan solusi untuk menghadapi perubahan global yang terjadi akhir-akhir ini. 
Munculnya konsep desa wisata menjadi stimulan bagi desa-desa untuk berlomba-lomba menjadikan desa wisata. pada tahun 2016, Kabupaten Sleman memiliki 39 desa wisata dengan 3 klasifikasi berbeda yaitu mandiri, berkembang, dan tumbuh. Seluruh desa wisata yang ada di Kabupaten Sleman telah tergabung dalam forum komunikasi desa wisata. Forum ini berguna sebagai wadah bagi pengelola desa wisata dalam mengembangkan desanya serta sebagai saran komunikasi antar pengelola desa wisata dan pemerintah daerah. ${ }^{1}$ Banyaknya desa wisata di Kabupaten Sleman, menjadikan Kabupaten Sleman dikenal sebagai daerah yang memiliki banyak desa wisata. jumlah desa wisata yang begitu banyak tersebut menimbulkan homogenitas desa wisata, hal ini membuat setiap desa wisata di Kabupaten Sleman terlihat sama dengan yang lainnya. Dalam kajian ini akan membahas 2 dari 39 desa wisata yang yang ada di Kabupaten Sleman, yaitu desa wisata Pulesari dan desa wisata Pancoh, alasan utama pemilikan dua lokasi ini adalah letak kedua desa yang tidak terlalu jauh dan telah ditetapkannya dua desa ini sebagai desa wisata kategori mandiri.

\section{Kerangka Pemikiran}

Dalam buku "An Introduction to Tourism and Anthropology" yang ditulis oleh Peter M. Burns, menyebutkan bahwa pentingnya pertemuan antara tuan rumah yang disebut sebagai 'host' dan tamu 'guest', menimbulkan adanya serangkaian interaksi lintas budaya dan ada berbagai argumen seputar gagasan 'tuan rumah' dan 'tamu'.

"The encounter between 'host' and 'guest' is of profound importance in the study of tourism. At least two main themes occur. First, a range of cross-cultural interactions which becomes of heightened significance for our purposes when there is disparity between the visitor and visited. Second, there is a range of arguments surrounding the notion of 'hosts' and 'guests'. The key point here is that the words are used in an ironic sense, the special rules that

\footnotetext{
${ }^{1}$ Laporan Akhir Kajian Klasifikasi Desa Wisata Kabupaten Sleman, Dinas Pariwisata Kabupaten Sleman Tahun 2018
} 
apply to willing hosts receiving invited guests in their home are suspended. The transaction becomes a commercial one"(Burns,1999:94)

Burns juga menyatakan dalam bukunya bahwa budaya termasuk pengalaman yang dipelajari secara social, termasuk didalamnya mencakup aspek menerima dan menjadi turis, bahkan Burns menjelaskan jika diskusi terkait 'budaya adalah segalanya' maka diskusi tentang budaya kehilangan makna yang lebih dalam. Faktorfaktor seperti hubungan sosiokultural antara 'tuan rumah' dan 'tamu' atau di mana budaya dapat dilihat sebagai komponen potensial untuk pengembangan produk, dan cara-cara di mana masyarakat di destinasi tertentu terstruktur tetap sangat penting bagi mereka yang mempelajari pariwisata.

Penelitian ini dapat dipandang sebagai studi banding dengan menggunakan penelitian komparatif. Penyelidikan ini dilakukan untuk membandingkan persamaan dan perbedaan dua peristiwa atau lebih, dan sifat-sifat objek yang diteliti, tergantung pada sikap tertentu. Menurut Nazir (2005: 58), studi banding adalah jenis studi deskriptif yang berusaha menemukan jawaban dasar sebab dan akibat dengan menganalisis kejadian atau faktor-faktor yang menyebabkan suatu fenomena tertentu. Oleh karena itu, studi banding adalah jenis studi yang digunakan untuk membandingkan dua atau lebih kelompok variabel tertentu.

Definisi yang menekankan dimensi sosial-budaya, khususnya aspek sejarah dan budaya adalah seperti yang diajukan oleh MacCannell, 1992 (dalam Herbert, 1995), sebagai berikut. "Tourism is not just an aggregate of merely commercial activities; it is also an ideological framing of history, nature and tradition; a framing that has the power to reshape culture and nature to its own needs".

Definisi di atas memandang Pariwisata bukanlah hanya kegiatan bisnis atau komersial semata, melainkan juga merupakan wahana bagi upaya untuk merevitalisasi sejarah, alam, dan kebudayaan. Dengan demikian pembangunan 
pariwisata berwawasan budaya di samping bertujuan untuk memperoleh manfaat bagi kesejahteraan ekonomi, juga memberi manfaat bagi pelestarian budaya dan lingkungan setempat.

\section{Gambaran Umum Desa Wisata Pulesari Dan Desa Wisata Pancoh}

Desa wisata Pulesari dan desa wisata Pancoh terletak di Kabupaten Sleman bahkan dua desa wisata ini memilik lokasi berdekatan yaitu tidak lebih dari $5 \mathrm{~km}$, namun memilik karakerteristik dan potensi wisata sangat berbeda. Berdasarkan pada laporan klasifikasi desa wisata Kabupaten Sleman, Desa wisata Pulesari maupun desa wisata Pancoh termasuk dalam kategori desa wisata mandiri. ${ }^{2}$ Kedua desa wisata ini memilik unique selling point berbeda, jika di desa wisata Pulesari menitik beratkan pada potensi alam berupa susur sungai, sedangkan di desa wisata Pancoh berupa alam sungai dan aktivitas pertanian. Sejak tahun 2016 desa wisata Pulesari telah dikategorikan sebagai desa wisata mandiri, sedangkan desa ekowisata Pancoh pada tahun 2016 dikategorikan sebagai desa wisata berkembang, namun di tahun 2018 mengalami peningkatan sehingga dapat dikategorikan sebagai desa wisata mandiri. Berikut gambaran karateristik desa wisata Pulesari dan desa wisata Pancoh

Tabel 1. Karakteristik desa wisata Pulesari dan desa wisata Pancoh

\begin{tabular}{llll}
\hline No. & Indikator & Desa Wisata Pulesari & Desa Wisata Pancoh \\
\hline 1. & Luas wilayah & 20.5 Hektar & 50 hektar \\
\hline 2. & Daya tarik & $\bullet \quad$ Sungai Bedok (susur sungai) & $\bullet$ Kebun Salak \\
& alam & $\bullet \quad$ Kebun salak & $\bullet$ Sungai Kaliadem (susur \\
& & & sungai) \\
& & & $\bullet$ Persawahan \\
\hline 3. & Day tarik & $\bullet$ & Jurit malam \\
& pendukung & & $\bullet$ Edukasi Biogas Sapi \\
\hline
\end{tabular}

2 Mengacu pada Klasifikasi desa wisata yang disusun Dinas Pariwisata Kabupaten Sleman dikategorikan menjadi 4 yaitu kategori 1) desa wisata rintisan, 2) desa wisata tumbuh, 3) desa wisata berkembang dan kategori paling bagus dan 4) desa wisata mandiri. Kriteria ini berdasarkan pada 8 unsur unsur yaitu 1) atraksi, 2) manajerian, 3) pemasaran, 4) aksesbilitas, 5) peran masyakat, 6) kunjungan wisatawan, 7) amenitas, 8) kepemilikan asset. Samakan jenis huruf 


\begin{tabular}{|c|c|c|c|}
\hline No. & Indikator & Desa Wisata Pulesari & Desa Wisata Pancoh \\
\hline & & $\begin{array}{l}\text { - Susur pedesaan (tracking } \\
\text { alam) }\end{array}$ & \\
\hline 4. & $\begin{array}{l}\text { Day tarik } \\
\text { budaya }\end{array}$ & $\begin{array}{ll}\text { - } & \text { kesenian Tari Salak } \\
\text { - } & \text { Kesenian Kubro Siswo } \\
\text { - } & \text { Kesenian Prajurit Bergodo } \\
\text { - } & \text { Kesenian Religi Hadroh. }\end{array}$ & $\begin{array}{ll}\text { - } & \text { Bermain gamelan } \\
\text { - } & \text { Petilan } \\
\text { - } & \text { Laras madyo } \\
\text { - } & \text { Tari Bung Beh } \\
\text { - } & \text { Tari Wireng }\end{array}$ \\
\hline 5. & $\begin{array}{l}\text { Daya tarik } \\
\text { buatan }\end{array}$ & $\begin{array}{l}\text { - Jembatan Goyang } \\
\text { - Titian Bambu }\end{array}$ & $\begin{array}{l}\text { - } \text { Bumi perkemahan dan } \\
\text { outbound } \\
\text { - Embung }\end{array}$ \\
\hline 6. & $\begin{array}{l}\text { Aktivitas } \\
\text { wisatawan }\end{array}$ & $\begin{array}{ll}\text { - } & \text { Jurit malam } \\
\text { - Susur pedesaan (tracking } \\
\\
\text { - } \text { alam) } \\
\text { - } \text { Butbound } \\
\text { - Melajar kesenian } \\
\text { - Memancing ikan }\end{array}$ & $\begin{array}{ll}\text { - } & \text { Belajar main gamelan } \\
\text { - } & \text { Susur sungai } \\
\text { - } & \text { Memetik salak } \\
\text { - } & \text { Aktivitas pertanian }\end{array}$ \\
\hline 7. & Aksesbilitas & $\begin{array}{l}\text { Dari pusat kota Yogyakarta } \\
\text { sejauh (20km) } \\
\text { - Jalan menuju lokasi sudah } \\
\text { beraspal dan mudah untuk } \\
\text { dilalui kendaraan kecil } \\
\text { maupun besar } \\
\text { - Penanda rambu lalu mintas } \\
\text { mudah dijumpai, dan jarak } \\
\text { tempuh menuju lokasi kurang } \\
\text { lebih } 1 \text { jam dari pusat kota }\end{array}$ & $\begin{array}{l}\text { - } 20 \mathrm{~km} \text { utara dari pusat } \\
\text { kota Yogyakarta } \\
\text { - Jalan menuju lokasi } \\
\text { beraspal dan mudah untuk } \\
\text { dilalui baik sepeda motor, } \\
\text { mobil, maupun bus besar } \\
\text { dengan waktu tempuh } \\
\text { kurang lebih } 1 \text { jam. } \\
\text { Penanda rambu lalu lintas } \\
\text { yang bertuliskan Pancoh } \\
\text { mudah ditemukan. }\end{array}$ \\
\hline 8. & $\begin{array}{l}\text { Kapasitas } \\
\text { manajerial }\end{array}$ & $\begin{array}{l}\text { - Terdapat struktur organisasi } \\
\text { pengurus yang telah } \\
\text { dibedakan antara pengelola } \\
\text { desa wisata dan pokdarwis } \\
\text { dan diperkuat dengan SK } \\
\text { yang sudah disampaikan } \\
\text { Dinas Pariwisata } \\
\text { - Semua pengurus sudah } \\
\text { memenuhi tugas pokok dan }\end{array}$ & $\begin{array}{l}\text { Terdapat struktur } \\
\text { organisasi penguruh yang } \\
\text { telah dibedakan antara } \\
\text { pengelola desa wisata dan } \\
\text { pokdarwis diperkuat } \\
\text { dengan SK yang telah } \\
\text { disampaikan Dinas } \\
\text { Pariwisata } \\
\text { Semua penguruh sudah } \\
\text { memahami tugas pokok }\end{array}$ \\
\hline
\end{tabular}




\begin{tabular}{|c|c|c|c|}
\hline No. & Indikator & Desa Wisata Pulesari & Desa Wisata Pancoh \\
\hline & & $\begin{array}{l}\text { fungsi serta peran dalam } \\
\text { melayani wisatawan. }\end{array}$ & $\begin{array}{l}\text { dan fungsi serta peran } \\
\text { dalam melayani } \\
\text { wisatawan }\end{array}$ \\
\hline 9. & $\begin{array}{l}\text { Peran serta } \\
\text { masyarakat }\end{array}$ & $\begin{array}{l}\text { Masyarakat sebagian telah } \\
\text { dilihatkan dalam kegiatan } \\
\text { desa wisata baik pemuda } \\
\text { maupun yang sudah } \\
\text { bekeluarga } \\
\text { - Hasil ekomoni yang didapat } \\
\text { dari usaha desa wisata telah } \\
\text { dirasakan secara menyeluruh } \\
\text { ke masyarakat }\end{array}$ & 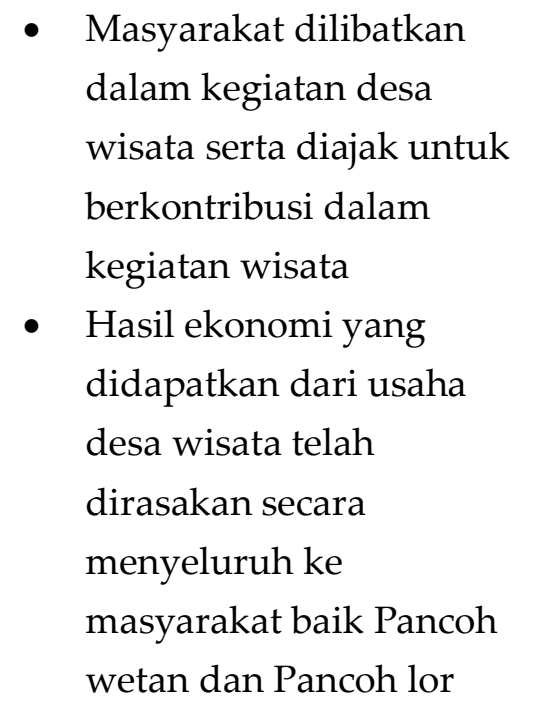 \\
\hline 10. & Amenitas & $\begin{array}{ll}\text { - } & \text { Homestay } \\
\text { - } & \text { MCK umum } \\
\text { - } & \text { Sekertariat } \\
\text { - } & \text { Alat kesenian } \\
\text { - } & \text { Memiliki } 9 \text { pendopo untuk } \\
& \text { menunjang kegiatan wisata } \\
\text { - } & \text { Mobil milik Desa } \\
\text { - } & \text { PKK } \\
\text { - Terdapat jaringan tambahan } \\
\end{array}$ & $\begin{array}{ll}\text { - } & \text { Homestay } \\
\text { - } & \text { Sekertariat } \\
\text { - } & \text { Alat kesenian sudah } \\
& \text { dimiliki, namun belum } \\
& \text { memilik panggung } \\
& \text { pementasan kesenian } \\
& \text { tersendiri. } \\
\text { - Ruang Gamelan } \\
\text { - } \text { Daur Ulang Sampah } \\
\text { - Ruang Pendopo }\end{array}$ \\
\hline 11. & Pemasaran & $\begin{array}{l}\text { Pemasaran dilakukan dengan } \\
\text { media social maupun mengikuti } \\
\text { pameran yang diadakan oleh } \\
\text { dinas pariwisata. }\end{array}$ & $\begin{array}{l}\text { Pemasaran dilakukan melalui } \\
\text { media social seperti } \\
\text { instagram, facebook maupun } \\
\text { blog serta mengikuti } \\
\text { pameran yang diadakan oleh } \\
\text { dinas pariwisata. }\end{array}$ \\
\hline 12. & Aspek pasar & $\begin{array}{l}\text { Secara garis besar jumlah } \\
\text { wisatawan yang datang ke Desa } \\
\text { Wisata Pulesari dilihat secara } \\
\text { geografinya, yaitu wisatawan } \\
\text { lokal, wisatawan nusantara }\end{array}$ & $\begin{array}{l}\text { Lokal, Regional berasal dari } \\
\text { Surabaya, Semarang } \\
\text { sedangkan wisatawan } \\
\text { mancanegara berasal dari } \\
\text { Asia, baik itu Jepang maupun } \\
\text { Thailand. Desa Ekowisata }\end{array}$ \\
\hline
\end{tabular}




\begin{tabular}{|c|c|c|c|}
\hline No. & Indikator & Desa Wisata Pulesari & Desa Wisata Pancoh \\
\hline & & $\begin{array}{l}\text { sejumlah dan wisatawan } \\
\text { mancanegara }\end{array}$ & $\begin{array}{l}\text { Pancoh sering dikunjungi } \\
\text { oleh wisatawan mancanegara } \\
\text { yang berasal dari Jepang, } \\
\text { China, Thailand yang datang } \\
\text { untuk suatu penelitian atau } \\
\text { summer camp di Jogja. }\end{array}$ \\
\hline 13. & $\begin{array}{l}\text { Kepemilikan } \\
\text { aset }\end{array}$ & $\begin{array}{l}\text { Tanah yang digunakan } \\
\text { merupakan tanah khas desa dan } \\
\text { tanah pribadi yang disewakan } \\
\text { setiap tahun oleh pengelola desa } \\
\text { wisata. }\end{array}$ & $\begin{array}{l}\text { Aset yang digunakan desa } \\
\text { wisata Pancoh merupakan } \\
\text { tanah kas desa yang disewa } \\
20 \text { tahun oleh pengelola desa } \\
\text { wisata. }\end{array}$ \\
\hline 14. & Invetasi & $\begin{array}{l}\text { Investasi yang ada di desa } \\
\text { wisata Pulesari secara garis besar } \\
\text { dibagi } 2 \text { bagian yaitu investasi } \\
\text { dari pemerintah daerah dan } \\
\text { investasi dari masyarakat desa } \\
\text { itu sendiri, investasi dari } \\
\text { pemerintah daerah berasal dari } \\
\text { pemda Sleman yang } \\
\text { menginvestasikan sejumlah } \\
\text { uang, sedangkan investasi dari } \\
\text { masyarakat adalah berupa } \\
\text { tenaga dan logistic untuk } \\
\text { memenuhi pembuata desa } \\
\text { wisata }\end{array}$ & $\begin{array}{l}\text { Investasi yang ada di lokasi } \\
\text { Desa Ekowisata Pancoh } \\
\text { adalah investasi dari Bumdes } \\
\text { Desa Girikerto. Contoh } \\
\text { investasi adanya landmark } \\
\text { bertuliskan Desa Ekowisata } \\
\text { Pancoh yang merupakan } \\
\text { bantuan dari Dinas } \\
\text { Pariwisata DIY Selain itu juga } \\
\text { adanya investasi berupa } \\
\text { bantuan untuk pembangunan } \\
\text { toilet. }\end{array}$ \\
\hline 15. & $\begin{array}{l}\text { Stakeholders' } \\
\text { yang } \\
\text { berperan } \\
\text { dalam } \\
\text { investasi }\end{array}$ & $\begin{array}{l}\text { Tiap masyarakat yang ada di } \\
\text { desa Pulesari adalah stakeholder } \\
\text { yang memiliki peran dalam } \\
\text { investasi di desa wisata tersebut, } \\
\text { bisa berupa tenaga, jasa maupun } \\
\text { uang, tak lupa juga bahan yang } \\
\text { menyediakan logistic. }\end{array}$ & $\begin{array}{l}\text { Desa Ekowisata Pancoh tidak } \\
\text { menerima investor asing } \\
\text { karena akan merasa di atur } \\
\text { dan tidak ada kesempatan } \\
\text { untuk mengatur destinasi ini } \\
\text { sesuai keinginan mereka. }\end{array}$ \\
\hline
\end{tabular}

Sumber: Hasil observasi lapangan, 2019

Tabel diatas memperlihatkan perbedaan potensi yang ada di desa wisata Pulesari dan desa wisata Pancoh meskipun lokasinya sangat berdekatan. Perbedaan ini juga terlihat pada pasar wisatawan yang berkunjungan, dimana di desa wisata 136 JUMPA Volume 8, Nomor 1, Juli 2021 
Pulesari jumlah wisatawan yang berkunjung tidak dibatas, namun berbeda dengan desa wisata Pancoh yang membatasi jumlah kunjungan wisatawan dengan alasan menjaga kelestarian alam dan lingkungan. Dapat dilihat jumlah kunjungan wisatawan 3 tahun terakhir terus mengalami peningkatan dari tahun ke tahun. Peningkatan tidak hanya terjadi pada jumlah kunjungan wisatawan saja, tetap juga pada jumlah homestay dan jumlah kamar yang disewakan.

Tabel 2. Jumlah Wisatawan dan homestay desa wisata Pulesari dan desa wisata Pancoh

\begin{tabular}{lccccc}
\hline Desa & \multicolumn{3}{c}{ Jumlah kunjungan wisatawan } & $\begin{array}{c}\text { Jumlah } \\
\text { homestay }\end{array}$ & $\begin{array}{c}\text { Jumlah } \\
\text { kamar }\end{array}$ \\
\cline { 2 - 4 } & $\mathbf{2 0 1 6}$ & $\mathbf{2 0 1 7}$ & $\mathbf{2 0 1 8}$ & & \\
\hline Pulesari & 52.974 & 63.297 & 34.113 Agustus & 57 & 150 \\
Pancoh & 2.633 & 7.331 & 8.780 November & 60 & 80 \\
& & & & & \\
\hline
\end{tabular}

Sumber: Kajian Klasifikasi Desa Wisata Kabupaten Sleman Tahun 2018

\section{Desa Wisata Pulesari}

Saat ini Desa Wisata Pulesari dikelola dan dikembangkan secara swadaya oleh masyarakat desa sendiri, mulai dari kepengurusan desa hingga pelayanan terhadap wisatawan melibatkan hampir semua komponen anggota masyarakat. Fasilitasfasilitas yang tersedia di Desa Pulesari juga merupakan hasil dari kerja bakti masyarakat, sehingga masyarakat bertanggung jawab atas keutuhan fasilitas wisata dengan merawat dan menjaga sebaik-baiknya. Hasil atau keuntungan yang didapat dari desa wisata dibagi rata kepada masyarakat yang terlibat, dan sebagian masuk ke dalam kas desa yang kemudian akan digunakan untuk kepentingan Desa Wisata Pulesari. Sama halnya dengan penuturan narasumber, Desa Wisata Pulesari ini dikelola oleh, dari dan untuk masyarakat desa. 
Desa Wisata Pulesari merupakan salah satu desa wisata yang sudah cukup berkembang, terbukti dengan adanya struktur kepengurusan yang dikelola langsung oleh masyarakat. Mulai dari Kepala Desa Wonokerto sebagai pelindung Desa Wisata Pulesari, penasehat dari Dukuh Pulesari serta terdapat susunan ketua hingga seksiseksi yang bertugas untuk meningkatkan pelayanan kepada wisatawan yang berkunjung ke Desa Wisata Pulesari.

Masyarakat Desa Wisata Pulesari cukup aktif terlibat dalam pengembangan desa wisata, terbukti dengan adanya inisiatif dari masyarakat untuk membangun fasilitas-fasilitas pariwisata yang dilakukan secara swadaya, keterlibatan dalam pengelolaan desa wisata, serta menyediakan homestay yang dapat digunakan wisatawan untuk menginap. Pemanduan di Desa Pulesari pun dilakukan oleh masyarakat baik dewasa maupun remaja ikut andil dalam kegiatan pemanduan untuk wisatawan. Walaupun tidak tersedia warung makan, namun wisatawan dapat memesan makanan yang akan dimasak oleh masyarakat Desa Pulesari dibawah pengawasan dari Bapak Riyanto dan Bapak Sarijo selaku seksi kuliner. Para remaja di Desa Pulesari ini juga aktif dalam kegiatan kesenian tradisional yang menjadi salah satu atraksi untuk menarik wisatawan. Sehingga dapat disimpulkan bahwa sebagian besar dari masyarakat Desa Pulesari ini aktif terlibat dalam pengembangan Desa Pulesari menjadi sebuah desa wisata.

\section{Desa Wisata Pancoh}

Desa Wisata Pancoh merupakan desa dengan konsep ekowisata yang berada di lereng Merapi, Kabupaten Sleman. Konsep ekowisata mendapat perhatian besar untuk melestarikan lingkungan dan sumber daya alam. Mayoritas masyarakat di desa wisata Pancoh memiliki lahan yang dimanfaatkan untuk menanam salak berbagai jenis diantaranya adalah salak Pondoh, salak Manggala, salak Gading maupun salak Madu. Dari berbagai jenis salak yang ada di desa wisata Pancoh, salak Pondoh yang 
dikelola perorangan maupun berkelompok merupakan salah satu tanaman yang sudah berumur 10 tahun. Selain belajar memetik salak, pengunjung juga dapat belajar cara menanam, memelihara dan dapat membeli buah salak dengan harga terjangkau.

Desa wisata Pancoh dikelola secara mandiri oleh warga, dan telah memilik struktur organisasi baik pada tingkah low manajemen, middle manajemen, maupun top manajemen. Dalam struktur organisasi dusun ketua RT dilibatkan dalam kepengurusan, dan diketua oleh Kepala Dusun. Desa wisata Pancoh juga salah satu desa wisata yang mengangkat nilai Budaya. Ini terbukti dari adanya rumah gamelan yang dikelola bersama oleh masyarakat dan di fungsikan bagi wisatawan yang berkunjung untuk menikmati bagaimana sensasi memainkan gamelan di pedesaan sampai akhirnya mementaskannya didepan umum bersama masyarakat lokal. Hal tersebut menjadi salah satu atraksi yakni pementasan gamelan kolaborasi wisatawan dengan masyarakat lokal yang dapat dilihat ketika berada di Desa Wisata Pancoh.

\section{Dampak Sosial Pariwisata Di Desa Wisata Pulesari Dan Desa Wisata Pancoh}

Berpedoman pada buku "Community Based Tourism" yang ditulis oleh Potjana Suansri (2003), maka dampak social yang ditimbulan dari kegiatan pariwisata berupa dampak negatif dan positif. Sejak berkembangnya pariwisata di desa wisata Pulesari dan desa wisata Pancoh terjadi perubahan social masyarakat diantaranya adalah manfaat ekonomi ekonomi, terciptanya lapangan pekerjaan dampak yang dirasakan oleh masyarakat sehingga menjadi perubahan yang sangat mudah dirasakan dalam jangka waktu pendek. Pada bagian ini akan membahas dampak positif dan negatif aspek sosial yang terjadi di desa wisata Pulesari dan desa wisata Pancoh diantaranya sebagai berikut :

\section{Dampak Positif Pariwisata Aspek Sosial}

Pertama, Semangat dari anggota komunitas (Community spirit) yang terbangun secara alami di desa wisata Pulesari. Bentuk semangat kebersamaan ini terlihat dari 
adanya kerjasama dan gotong royong yang dilaksanakan di desa wisata Pulesari. Pada saat observasi dilaksanakan Desa wisata Pulesari sedang membangun dan memperbaik salah satu dari 9 pendopo yang ada. Bentuk kerjasama ini dilakukan secara sukarela oleh suluruh warga lak-laki dewasa, pada saat kondisi wisatawan sedang low season, meskipun tanpa ada pembagian tugas yang jelas. Hal ini mencerminakan social structure yang terjalin cukup baik didesa wisata Pulesari.

Selain itu di desa ini partisipasi masyarakat dalam kegiatan wisata tidak hanya diikut oleh golongan tua tetapi juga pemuda, terbukti dari banyaknya anak muda terlibat dan berperan sebagai pemandu wisata. Terdapat kurang lebih 150 pemandu wisata di Desa Wisata Pulesari, mulai dari pemandu dewasa hingga pemandu remaja. Dalam hal pemanduan wisata ini dikelola langsung oleh masyarakat dibawah pengawasan seksi pemandu. Para pemandu ini akan mendapat pembinaan dari seksi pemandu mengenai tata cara memandu wisatawan, selain itu mereka akan mengikuti pelatihan memandu yang diadakan diluar Desa Wisata, sehingga dapat meningkatkan kemampuan dari masyarakat desa ini. Pembagian untuk pemandu dewasa dan remaja ini nantinya akan disesuaikan dengan permintaan dari rombongan wisatawan.

Berbeda dengan desa wisata Pulesari, Desa wisata Pancoh tidak tergambar adanya semangat dan kebersamaan komunitas dalam kegiatan pariwisata, meskipun telah ditentukan tugas pokok dan fungsi masing-masing bagian sesuai struktur organisasi, bahkan hanya Community leader yang berperan aktif dalam kegiatan pariwisata. Berdasarkan struktur organisasi hanya terlihat pada level top manajement yaitu Ngatijan sebagai ketua pengelola dan middle manajement yang terdiri dari keuangan, manajemen, dan sekertaris. Kurangnya partisipasi masyarakat dalam kegiatan pariwisata disebabkan karena pariwisata bukan menjadi sektor penghasilan utama didesa ini, melainkan bertani dan berkebun, sehingga banyak dari masyarakat lebih memilih untuk bertani dan berkebun. Meskipun demikian tidak sedikit pemuda 
yang andil untuk menjadi pemandu wisata meskipun kurang memiliki wawasan yang cukup luas, sehingga dapat dikatakan desa wisata Pancoh ini kurang memadai di bagian pemandu wisatanya.

Kedua, memperkuat organisasi (strengthening organization) salah satu dampak positif yang dapat diperhitungkan dengan adanya keterbukaan antar masyakarat dan pembagian hasil secara merata sesuai dengan bagian masing-masing. Pada desa wisata Pulesari struktur bagi hasil telah ditetapkan dan disepakat bersama adalah 70 banding 30 dimana uang masuk lewat masyarakat sebanyak $70 \%$ dan $30 \%$ menjadi hak secara pribadi. Dengan demikian, maka ada dana yang dapat dipergunakan untuk kegiatan dan pengembangan desa, baik dalam bentuk fisik maupun nonfisik, sehingga memperkuat eksistensi dan keberlangsungan wisata didesa ini, seperti contoh kegiatan pelatihan Pemanduan wisata, pelatihan pengolahan makanan tradisional, pelatihan penyusunan paket wisata, pembangunan dan perbaikan sarana dan prasarana seperti pendopo dan toilet.

Pada desa wisata Pancoh, dalam struktur bagi hasil dalam pengelolaan desa yang diterima Desa wisata Pancoh akan membagi hasilnya untuk beberapa hal yaitu: a) Fee untuk pemandu, b) Fee untuk pemilik homestay, c) Setiap hari raya idul fitri membuat bingkisan, d) Membuat sarana dan prasarana Desa Ekowisata Pancoh meskipun tidak disebutkan secara langsung berapa persen yang akan masuk kedalam kas desa wisata. Salah satu bentuk untuk memperkuat organisasi desa wisata Pancoh yaitu dengan bergabung pada Forum Komunikasi Desa Wisata (Forkom). ${ }^{3}$

Ketiga, munculnya pemimpin (Emergence of leader) pada bagian terdapat 3 poin utama yang dapat dijadikan tolak ukur dampak positif yaitu, berbagi pengalaman dari anggota komunitas desa wisata maupun dengan tamu, pendelegasian tugas kepada masing-masing anggota, dan kebanggan anak muda terhadap desanya. Desa

\footnotetext{
${ }^{3}$ Ini merupakan salah satu wadah bagi para pelaku, pengagas, dan pengiat desa wisata, dengan tujuan untuk saling bertukar informasi dan pengalaman dalam hal pengembangan desa wisata.
} 
wisata Pulesari banyak dikunjung wisatawan dalam jumlah besar (mass tourism) namun mampu dikelola dengan baik. Terbukti dari hasil observasi terlihat bahwa pada bagian oprasional, pemandu wisata, reservasi, maupun ibu-ibu yang memasak mampu melakukan tugas. Kemampuan pemandu wisata mengemas dan meyajikan informasi di desa ini memberikan pengalaman sendiri bagi wisatawan dan terjadi interkasi antara wisawan dengan pemandu wisata. Disamping itu pedelegasian tugas bagi kaum muda dilakukan dengan menyusun media promosi melalui social media baik malalui Facebook, dan Instragram, serta para remaja di Desa Pulesari ini juga aktif dalam kegiatan kesenian tradisional yang menjadi salah satu atraksi untuk menarik wisatawan, hal ini yang akan memunculkan rasa bangga terhadap budaya dan desanya.

Desa Wisata Pancoh memiliki permasalahan di aspek SDM. Walaupun di Desa Wisata Pancoh memiliki banyak pemuda namun sebagian besar yang ikut andil dalam mengelola Desa Wisata ini hanyalah kaum Senior seperti bapak-bapak dan Ibuibu yang ada di Desa Wisata ini. Namun, sekarang para kaum pemuda sudah mulai ikut andil dalam mengelola Desa Wisata Pancoh seperti menjadi pemandu. Kendala yang dialami kaum senior Desa Wisata Pancoh ini yaitu ketika hari kerja kekurangan SDM dikarenakan para pemuda yang masih bekerja ataupun kuliah sehingga hanya kaum senior saja yang bisa menghandle para wisatawan yang datang pada saat weekdays. Selain itu mengingat adanya beberapa turis asing yang pernah datang ke Desa Wisata Pancoh juga memiliki kendala dalam berkomunikasi seperti menggunakan bahasa Inggris, sehingga perlu adanya bantuan dari pemuda yang memilik kemampuan berbahasa Inggris.

\section{Dampak Negatif Pariwisata Aspek Social}

Pertama, dampak yang terjadi pada komunitas (Community division) dalam hal ini desa wisata baik itu berupa migrasi, orang luar bermigrasi ke desa wisata, maupun 
kurangnya kepercayaan pada identitas sebagai desa wisata. Berdasarkan hasil wawancara dan observasi baik didesa wisata Pulesari maupun desa wisata Pancoh, migrasi terjadi di dua desa wisata ini. Tidak sedikit pasangan usia muda, yang melakukan mirgasi dengan tujuan utama meningkatkan pendapatan, karena dirasa bekerja pada sektor wisata di desanya tidak menjajikan dan hanya bersifat musiman. Sebaliknya, tidak ada orang luar yang bermigrasi ke desa wisata Pulesari dan Pancoh dengan tujuan menetap maupun tujuan ekonomi. Masyarakat di dua desa wisata ini, mampu berdiri secara mandiri dan mempertahankan eksistensi sebagai desa wisata yang pada akhir ditahun 2018 ditetapkan sebagai desa wisata mandiri.

Kedua, permasalah social (social problems) terkait dengan obat-obat terlarang maupun prostitusi. Selama ditetapkannya sebagai desa wisata baik di Pulesari maupun Pancoh belum pernah terjadi tindakkan kriminal yang berkaitan dengan obat terlarang, maupun pencurian. Meskipun dua desa ini terletak tidak jauh dari Kaliruang dimana kawasan ini memilik banyak penginapan yang dimanfaatkan untuk tujuan prostitusi, namun homestay yang ada di desa wisata Pulesari dan Desa wisata Pancoh hanya diperuntukkan bagi wisatawan yang menginap dengan tujuan berwisata, malam keakraban, camping, outbound dan rombongan keluarga, sehingga di dua desa ini tidak ditemukan masalah social yang berkaitan dengan prostitusi.

Ketiga, konflik (Conflict) mulai bermunculan desa wisata baru di sekitar Desa Wisata Pulesari. Desa desa wisata akan saling bersaing untuk mendapatkan pengunjung. Desa Wisata Pulesari harus terus berkembang agar tidak kalah dengan desa wisata lainnya. Seperti Desa Wisata Barongan yang mulai dibuka pada tahun 2014 dan memiliki atraksi yang hampir sama dengan Desa Wisata Pulesari yaitu tracking sungai dan outbound. Konflik lain yang terjadi adalah kesalahpahaman dalam manajemen oprasional yang disebabkan oleh komunikasi dua arah yang tidak terkoordinir, seperti pembagian jumlah wisatawan dengan pemandu wisata, alur pemanduan, pembagian homestay yang akan digunakan, hingga pada pembagian 
penyiapan konsumsi bagi tamu. Meskipun sudah ada pembagian tugas dan kesepakan di awal, namun konflik seperti ini masih dapat terjadi pada saat jumlah kunjungan tamu meningkat (high season). Namun demikian konflik yang terjadi didesa wisata Pulesari hanya pada manajemen oprasional, dan tidak ada konflik yang mengakibatkan perubahan sikap, prilaku dan interaksi social di kalangan masyarkat.

Sedangkan di desa wisata Pancoh konflik yang terjadi adalah keberlangsungan pengelolaan, regenerasi kepada para pemuda desa. Masalah utamanya yaitu tidak adanya generasi muda yang mau mengelola desa wisata, sehingga tidak ada regenerasi, hal ini disebabkan karena anak milenial (zaman sekarang) tidak ada ketrtarikan untuk bergerak aktif memajukan desa wisata. Belum lagi pengetahuan desa yang memiliki julukan desa ekowisata yang seharusnya para pemuda tahu maknanya dan secara aplikatifnya, sedangkan sampai saat ini yang sering aktif mengambil bagian dalam kegiatan pariwisata adalah generasi orang tua. Dari pihak pengelolaan yang diharapkan dari ketua pengelola desa wisata Pancoh adalah adanya regenerasi untuk mengelola desa wisata Pancoh ini secara berkelanjutan dan jangka panjang.

\section{Dampak Budaya Pariwisata Di Desa Wisata Pulesari Dan Desa Wisatan Pancoh}

\section{Dampak Positif Pariwisata Aspek Budaya}

Pertama, pelestarian kebudayaan lokal (Preservation of local culture). Tidak hanya melestarikan budaya yang ada desa wisata Pulesari tetapi juga menciptakan kesenian Tari Salak. Selain Tarian Salak ini kesenian lainnya seperti Kesenian Kubro Siswo, Kesenian Prajurit Bergodo, dan Kesenian Religi Hadroh. Kesenian Kubro Siswo atau di desa ini sudah dikembangkan untuk daya tarik tersendiri menjadi Tari Kobro "Putro Mudo" ini adalah sebuah kesenian Tari Kobro Desa Pulesari yang bernuansa religi untuk dikolaborasikan dengan gamelan dan musik-musik Islami. Tari Kobro "Putro Mudo" yang diisi dengan pemain tari pemuda-pemuda yang 
menggambarkan seorang pemuda-pemuda yang seperti anshor atau pengawal Nabi Muhammad Shallallahu Alaihi Wasallam yang berjuang bersama dalam menegakkan ajaran Islam, yang ditunjukkan oleh adanya peperangan.

Pelestarian budaya yang terjadi di desa wisata Pancoh diantaranya adalah 1) Petilan, merupakan sepenggal cerita wayang orang yang akan ditampilkan berdasarkan permintaan dari wisatawan, 2) Laras Madyo kesenian tradisional yang pada awaalnya merupakan kesenian islam dari kasunanan Surakarta Hadiningrat yang mempunyai misi dakwah. Laras madyo pada desa wisata Pancoh yang dilaksanakan latihannya sebulan sekali dan tampil saat ada acara pengajian atau acara tertentu, 3) Bung Beh merupakan tarian anak-anak yang musiknya berasal dari klenting yang ditampilkan saat malam perpisahan ketika ada perminaan dari wisatawan, 4) Tari Wireng yang biasa ditampilkan berdasarkan berdasarkan permintaan wisatawan, sehigga wisatawan dapat langsung belajar menari dan memahami cerita tarian. Tari ini diciptakan untuk menyemangati 4 prajurit perang saat itu sedang berlatih.

Kedua, pertukaran informasi (information exchange) antara tuan rumah dan tamu (HostEguest) terkait dengan potensi desa, kesenian, tradisi, adat istiadat, gaya hidup maupun budaya yang pada akhirnya menimbul inteaksi lebih mendalam. Pada desa wisata Pulesari petukarang infomasi dapat dilakukan pada saat wisatawan melakukan aktivitas berwisata, sebagai contoh pada saat wisatawan menyasikkan tarian salak, sehingga pemandu wisata menjelaskan deskripsi tarian salak. Banyaknya potensi budaya di desa wisata Pulesari, berdampak pada rasa ingin tahun wisatawan tentang makna, sejarah dan alur cerita tarian tesebut, ini yang dimaksud pertukatan informasi terkait budaya lokal setempat.

Sedangkan pada desa wisata Pancoh, pertukuran informasi terjadi pada saat proses pemanduan. Pada Desa wisata Pancoh terdapat kata-kata mutiara Jawa yang mengandung arti dan makna yang di tunjukkan sepanjang jalan Desa Ekowisata 
dengan tujuan melestarikan bahasa jawa dan memberikan kata-kata berkesan yang memiliki makna pada wisatawan. Pertukaran informasi dan pengalaman juga dapat terjadi pada saat wisatawan membuat batik dengan motif parijotho atau dengan nama lain Batik Sinom Parijotho.

\section{Dampak Negatif Pariwisata Aspek Budaya}

Pertama, komersialisasi budaya (Ahimsa, 2011). komersialisasi (commercialisation) berarti "memperdagangkan", yang bisa dimaknai sebagai sesuatu yang positif, bisa juga negatif, tergantung pada apa yang diperjual-belikan. Komersialisasi anak, perempuan, atau tubuh misalnya, dipandang oleh sebagian masyarakat sebagai hal yang negatif. Demikian juga misalnya komersialisasi kesenian, komersialisasi pendidikan. Komersialisasi sebagai suatu gejala social budaya yang muncul karena adanya situasi dan kondisi social budaya tertentu, yang memugkinkan komersialisasi tumbuh dan berkembang dalam masyarakat. ${ }^{4}$

Komersialisasi yang terjadi di desa wisata Pulesari berupa penciptaan tarian salak. Tarian salak bisa masuk dampak positif maupun dampak negatif. Tarikan salak diciptakan guna menambah dan melengkapi atraksi wisata yang dapat dinimati wisatawan selam berada di desa Pulesari, bahkan tarian ini disajikan sesuai dengan permintan tamu. Atraksi wisata berupa tarian ini merupakan bagian dari komersialisasi budaya mengingat harga paket wisata untuk menyaksikan tarian ini tidaklah murah. Hal ini merupakan bagian dari Culture degeneration (culture creation for tourism)

Pada desa wisata Pancoh bentuk komersialisasi terlihat pada kebudayaan atau gaya hidup masyarakat yang dijual kepada wisatawan yang datang, dimana gaya

\footnotetext{
${ }^{4}$ Tulisan ini berjudul "Pariwisata Di Desa Dan Respon Ekonomi; Kasus Dusun Brayut di Sleman, Yogyakarta", ditulis pada jurnal Patrawidya vol.12 no. 4 halaman 635-842. Jurnal ini memberikan gambaran bagaimana respon ekonomi yang diperoleh warga dusun ketika pariwisata mulai disadari sebagai sebuah peluang untuk mendapatkan tambahan penghasilan.

146 JUMPA Volume 8, Nomor 1, Juli 2021
} 
hidup atau tradisi yang dilakukan masyarakat Desa Pancoh menjadi daya tarik tersendiri. Terdapat lima kebudayaan yang dijual dalam paket wisata, walaupun bukan musim perayaan namun wisatawan bisa tetap melihat tradisi-tradisi tersebut bahkan turut ikut serta dalam perayaan tradisi tersebut. 1) Upacara Wiwit, ini merupakan upacara untuk mengawali masa panen biasanya masyarakat Desa Pancoh melakukan upacara Wiwit saat panen padi sebagai ucapan syukur atas berhasilnya panen, dan biasanya upacara ini diiringi dengan doa-doa dan sesaji sebagai ucapan syukur dan hormat kepada Dewi Sri sebagai pemberian rezeki dalam bentuk panen, 2) Nyandran, merupakan salah satu upacara tradisional yang masih dilakukan di Desa Pancoh yang merupakan upacara pembersihan makam leluhur oleh warga setempat. Tradisi ini bisa disaksikan oleh wisatawan bahkan bisa diikuti oleh wisatawan, karena upacara Nyandran masuk kedalam paket wisata yang dijual 3) Kenduri atau upacara Kenduri yang merupakan perwujudan rasa syukur masyarakat terhadap terkabulnya harapan. Namun biasanya upacara ini dilakukan sebagai penyambutan tamu oleh masyarakat Desa Pancoh, 4) Njenangi atau upacara kelahiran bayi atau biasanya di kenal dengan aqiqah. Seperti biasa wisatawan tidak perlu menunggu adanya bayi yang lahir untuk dilaksanakannya upacara yang satu ini. masyarakat akan melakukan upacara Njenangi ini sesuai dengan urutan atau bagian-bagian yang dilakukan pada umumnya sebagai permintaan dari wisatawan, 5) Mitoni atau upacara 7 bulanan, upacara ini dilakukan persis ketika melakukan upacara 7 bulanan yang akan diadakan penyiram dan pembacaan doa-doa agar Ibu dan bayi dalam kandungan selamat hingga saatnya lahiran.

Kedua, meniru budaya lain (imitate another culture) yang terjadi tidak hanya pada desa wisata Pulesari tetapi juga desa wisata Pancoh. Tidak hanya meniru pada aspek budaya saja, tetapi juga atraksi dan akivitas yang disajikan kepada wisatawan, sehingga hal ini mengakibatkan homogenitas di desa wisata. sebagai contoh tradisi yang dilakukan didesa wisata Pancoh seperti tradisi wiwitan, tradisi nyadran, tadisi 
genduri, tradisi jenangan, tradisi mitoni juga dapat ditemukan di desa wisata lain, Sedangkan pada desa wisata Pulesari aktivitas wisata yang dilakukan sama dengan yang ada di desa wisata Desa Wisata Barongan yang mulai dibuka pada tahun 2014 dan memiliki atraksi yang hampir sama yaitu tracking sungai dan outbound. Atarksi budaya yang di jual desa wisata pada dasarnya hampir sama dan masing-masing desa wisata menglaim bahwa tradisi tersebut asli dari desanya.

\section{Kesimpulan}

Penelitian ini yang dilaksanakan pada dua desa yang terletak di Kabupaten Sleman yaitu desa wisata Pulesari dan desa wisata Pancoh, yang pada tahun 2019 telah ditetapkan sebagai desa wisata mandiri, dan memilik permasalahan dan karakteristik yang berbeda. Semenjak dua desa ini ditetapkan sebagai desa wisata berbagai fenomena dan konflik tidak dapat dihindari, khususnya dampak social budaya yang terjadi. Dampak Positif dan negatif yang terjadi pada desa wisata Pulesari dan Pancoh mengakibatkan perubahan struktur social masyarakat, dan memunculkan dinamika sosial (social dynamics) yang tidak dapat dihindari. Selain itu Interaksi antara masyarakat lokal sebagai (host) dan wisatawan sebagai (guest) secara langsung maupun tidak langsung terjadi, bahkan sampai pada perubahan pola prilaku masyarakat.

Dampak sosial budaya yang terjadi pada desa wisata Pulesari dan Pancoh dapat berupa dampak positif maupun dampak negatif. Adapun dampak positif yang terjadi antara dua desa ini sangat berbeda, secara garis besar dampak positif yang terjadi diantaranya pada aspek sosial adalah : 1) Semangat dari anggota komunitas (Community spirit) yang terbangun secara alami di desa wisata Pulesari, 2) memperkuat organisasi (strengthening organization) salah satu dampak positif yang dapat diperhitungkan dengan adanya keterbukaan antar masyakarat dan pembagian hasil secara merata sesuai dengan bagian masing-masing,3) munculnya pemimpin 
(Emergence of leader) pada bagian ini ada 3 hal utama yang dapat dijadikan tolak ukur dampak positif yaitu, berbagi pengalaman dari anggota komunitas desa wisata maupun dengan tamu, pendelegasian tugas kepada masing-masing anggota, dan kebanggan anak muda terhadap desanya. Sedangkan dampak negatif aspek social diantaranya 1) dampak yang terjadi pada komunitas (Community division) dalam hal ini desa wisata baik itu berupa migrasi, orang luar bermigrasi ke desa wisata, maupun kurangnya kepercayaan pada identitas sebagai desa wisata, 2) permasalah social (social problems) terkait dengan obat-obat terlarang maupun prostitusi, 3) konflik (Conflict) mulai bermunculan berupa timbulnya desa wisata baru yang mengusung konsep yang sama sehingga akan mejadi pesaing serta kesulitan dalam mencari dan mengerakkan generasi muda untuk ambil bagian dalam pengelolaan wisata.

Adapun dampak positif aspek budaya yang terjadi diantaranya adalah 1) pelestarian kebudayaan lokal (Preservation of local culture), 2) pertukaran informasi (information exchange) antara tuan rumah dan tamu (HostEguest) terkait dengan potensi desa, kesenian, tradisi, adat istiadat, gaya hidup maupun budaya yang pada akhirnya menimbul inteaksi lebih mendalam. Sedangkan dampak negative yang terjadi meliputi 1) komersialisasi budaya, 2) meniru budaya lain (imitate another culture).

Tidak dapat dipungkiri, bahwa aktivitas pariwisata tidak dapat dihindari dari adanya dampak positif maupun dampak negatif, bahkan banyak yang mempertanyakan "apakah pariwisata itu membangun atau menghancurkan?" pertanyaan ini muncul karena cukup banyak dijumpai dampak negatif pariwisata terjadi di objek wisata. Sesungguhnya, masyakat setempat (host community dan local commnity) tidak dapat menutup diri tehadap kedatangan wisatawan yang berkunjung ke desa wisata Pulesari maupun desa wisata Pancoh, justru karena kedatangan wisatawan tradisi dan budaya setempat maupun potensi alam menjadi lebih berarti dan bernilai. Oleh karena itu respon terhadap kunjungan wisatawan yang membawa 
dampak positif maupun negatif, dengan cara mengenalkan dan menimbulkan rasa ingin tahu wisatawan terhadap potensi desa sehingga mampu menarik wisatawan untuk berkujung ke desa wisata ini.

\section{Daftar Pustaka}

Ahimsa Putra. H.A (ed.). 2000. Ketika Orang Jawa Nyeni. Yogyakarta: Yayasan Galang

Burns, Peter \& Holden. 1984. An Introduction to Tourism and Anthropology. London: Routledge.

Cooper at. All. 1998. Tourism principles and practice. Englang : Longman

Gunn, C. A dengan Var, Turgutc. 1994. Tourism Planning: Basics, Concepts, Cases, $4^{\text {th }}$ edition. New York: Routledge

Herbert, David T., 1995.: Heritage Places, Leisure and Tourism, 1-20 dalam Herbert, David T., Heritage, Tourism, and Society, 228 p., Pinter, Great Britain.Bagus dalam bukunya "Diktat Antropologi Pariwisata". 2017.

I Gede Pitana., 2009. Pengantar Ilmu Pariwisata. Yogyakarta: Penerbit Andi

Ika Putra., 1985. Desa Wisata Kasongan, Skripsi, Jurusan Arsitektur, Fakultas Teknik, Universitas Gadjah Mada, Yogyakarta. fenomena sosial budaya yang ditimbulkan pariwisata (Pitana \& Gayatri, 2005)

Mathieson, A. Dan Wall, G. 1982. Tourism: Economic, Physical and Social Impacts. Harlow: Longman.

Nazir, Moh. 2005. Metode Penelitian. Jakarta: Ghalia Indonesia.

Nyoman S.1990. Pendit, Ilmu Pariwisata "Sebuah Pengantar Perdana. Jakarta: PT. Pradana Paramita hlm. 79-80

Nettekoven, Lothar. 1976. "Mechanism of Intercultural Interaction" dalam Emanuel de Kudt (ed.): Tourism Pasport to Development. New York : Oxford University Press

Raharjana, Destha Titi. 2005. "Pengembangan Desa Wisata Berbasis Budaya (Kajian Etnoekologi Masyarakat Dusun Ketingam, Desa Tirtoadi, Kecamatan Mlati Kabupaten Sleman, DI Yogyakarta)". Tesis, Program Studi Ilmu Lingkungan, Sekolah Pascasarjana, Universitas Gadjah Mada, Yogyakarta.

Smith, valene L. (ed.). 1989. Hosts and Guests The Anthropology of Tourism Second Edition. Philadelphia : University of Pensylvania. 
Wahab, Salah. 1996. Manajemen Kepariwisataan. (Alih bahasa : Frans Gomang). Jakarta : PT. Pradnya Paramita.

\section{Profil Penulis}

Elisa Dwi Rohani, S.E., M.Sc., CHE merupakan salah satu dosen Program Studi Diploma 4 Bisnis Perjalanan Wisata, Sekolah Vokasi Universitas Gadjah Mada yang saat ini sedang menempuh Program Pendidikan Doktoral Kajian Pariwisata Sekolah Pascasarjana Universitas Gadjah Mada. Bidang keahlian penulis lebih kepada bisnis perjalanan wisata, wisata minat khusus. Selain sebagai pengajar Penulis menjadi salah satu Asesor Bidang Usaha Perjalanan Wisata serta Auditor Biro Perjalanan Wisata.

Dr. Nuryuda Irdana, S.P., M.M., CHE merupakan salah satu dosen Program Studi Diploma 4 Bisnis Perjalanan Wisata, Sekolah Vokasi Universitas Gadjah Mada. Beliau menyelesaikan Program Pendidikan Doktoral Kajian Pariwisata Sekolah Pascasarjana Universitas Gadjah Mada ditahun 2019, dan saat ini menjabat sebagai Kepala Program Studi Diploma 4 Bisnis Perjalanan Wisata, Sekolah Vokasi Universitas Gadjah Mada Bidang keahlian beliau adalah Ekomomi Pariwisata, Manajemen Sumber Daya Manusia, serta Kewirausahaan. 